\title{
Security as a Selective Project
}

\author{
ALICE HILLS \\ School of Politics and International Studies, University of Leeds
}

ABSTRACT Security is a selective project that is typically understood, produced and expressed in terms of differentiation and exclusion; it is rarely for all. This is notably so in post-conflict cities such as Baghdad and Basra, where the principal political weapons are coercion and intimidation, territoriality is a significant facet of security's physical dimension and exclusionary tendencies, and security's referent object is an ethnic or sectarian identity or group. Friction exists between the multiple perspectives and interests concerned, and concessions and trade-offs are essential. Even so, it is probably not possible to develop citywide security, or, indeed, a comprehensive understanding that integrates state, sub-state (that is, factional) and individual security. Trends in Iraqi policing support this interpretation. International efforts to use a reformed public police to rebalance the provision of security more equitably are accordingly unrealistic.

Anyone considering post-conflict cities is struck by the extent to which security is the central point around which debate and competition take place. Security's absence or fragility dominates the lives of all those living or operating in cities such as Baghdad and Basra in the aftermath of the U.S.-led invasion of 2003, while the recruitment and responsibilities of those expected to restore, enforce or maintain security are manipulated by international actors and indigenous strongmen alike. At the same time, security is a multi-faceted social phenomenon, incorporating individual and public aspects and spaces, and its meaning accommodates multiple interpretations. International militaries impose minimal levels of street-level security in order to protect their own forces, and because they want to hand over responsibility to an indigenous public police as soon as it is practically or politically appropriate to do so. Meanwhile local strongmen and sectarian militia use physical security to shape the conduct of individuals and groups in furtherance of personal or exclusionary objectives. The poor or vulnerable are more aware of security's physical dimension: security means that they are not forcibly displaced, raped, robbed, kidnapped, mutilated, tortured or killed.

Common security projects, or projects that can be extended to all inhabitants, are rare, if not impossible. Typically, security is enjoyed by a few in isolation, or by specific groups in certain neighbourhoods. This may be a short-term solution, which creates the conditions for insecurity in the long-term, but the strongmen, sectarian militia and gangs seeking to access city resources do not think in the long term. They 
are more concerned about manipulating security as early as possible. Neither do they share liberal democracies' inability to decide whether security is a common or selective project. They are more aware that in the long-term security can be defined only in terms of the system of political competition that has grown up inside the city or country concerned (Lee, 1969, p. 9). Hence the selective and manipulative nature of security provision, and the mosaic of insecurity and injustice that results.

It makes analytical sense to explore these issues in the context of cities, for security is a relational issue (it cannot exist in isolation), and cities are a uniquely human environment built on networks of relationships. This is not to suggest that the dynamics of urban security provision are sufficiently different to justify treating urban and rural security as separate categories. Rather, it is to argue that cities have a political, cultural and physical value that rural areas lack, so the presence or absence of security takes on a special significance. Further, urbanization is associated with demographic change, which typically leads to the emergence of the youthful but alienated populations commonly linked to instability and insecurity. In other words, cities' known history means that they offer a laboratory in which to trace the social and political continuities moulding the provision of security. Cities offer discrete case studies of security, of who provides it, and how, and whose needs are prioritized.

Based on the paradigmatic examples of Baghdad and Basra, I argue that security is rarely (if ever) for all. In Iraq, security is, as in most post-conflict cities, based on relations of domination and coercion, rather than shared norms, and is typically produced and expressed in terms of differentiation and exclusion. The time frame used runs from April 2003, when U.S. forces took Baghdad and UK forces occupied Basra, to 2007, and the emphasis is on the early months of the occupation, when the Coalition Provisional Authority (CPA) sought to ensure its own security. But Iraq's chronic insecurity makes it impossible to tell whether the post-conflict period ended in June 2004, when the US formally handed sovereignty to an interim government, or in May 2005 when the first democratically elected Iraqi government was sworn in, or in late 2007, when a surge in U.S. troop numbers dramatically reduced insurgent attacks. There were improvements throughout this period, but they tended to be local; the presence of U.S. troops damped down violence, which then migrated to areas with fewer troops. Damningly, Johns Hopkins Bloomberg School of Public Health estimated that some 655,000 people died in Iraq between 2003 and 2005 (Johns Hopkins, 2006). This suggests that the nature, shape, functions, and dynamics of urban security are determined by cities being a uniquely human environment, in which the most significant threats tend to be manmade. Consequently, the greatest insight into the meaning of security in an urbanizing world is not via notions relating to long-term concerns such as human security. Rather, it is to be found via the classic question: When and where do I feel safe?

The case of Iraq is for such reasons significant. It enables us to explore classic empirically-based questions concerning security in terms of for whom and from what; about whether the concerns of the state should be prioritized over those of individuals or of groups based on religious or sectarian divisions, and individuals over groups or vice versa; and whether or not the various approaches may be combined into a coherent and meaningful whole, or whether one is dependent on the other. Iraq makes clear, too, that international efforts to rebalance security provision 
by using public police as a tool for social engineering are unrealistic, for police behaviour reflects the friction existing between multiple indigenous (as well as international) perspectives and interests.

This argument is developed in five sections, which address three basic questions: How is security understood? How is it produced? How is it expressed? The first section notes how crosscutting environmental issues affect the understanding, production and distribution of security. Of these, exclusion and territoriality are key. The second section considers the provision of security by police, while the third identifies ways in which crime and policy incoherence affect security provision. The fourth section discusses two dominant responses evident in Iraqi cities, which are ghettoization in Baghdad, and sectarianism in Basra. Section five concludes that the only certainty is that security (both for those who provide it, and often for those who want it) means whatever powerful actors make of it.

\section{Understanding Security}

Security is a multi-faceted and fetishized concept (Neocleous, 2000, p. xii). There are always marked differences between the security priorities and practices of military forces, international police advisers, indigenous police and the populace in post-conflict cities, but definitions of security are now commonly stretched to incorporate a range of meanings that include food, water, health and environmental issues for both individuals and communities. This is to some extent reasonable, for security is often defined situationally and contextually. Hence the American troops who drove around Baghdad "announcing in a loudspeaker 'security for us in return for electricity for you'” (Abdelhadi, 2003). Even so, it downplays three of the most significant characteristics of security: its relational, physical and territorial aspects.

Security cannot exist in isolation; it is always defined in relation to something or someone. It is not a resource that can be banked, but must be manipulated and managed. Further, security's meaning is defined broadly or narrowly, according to context. Coalition authorities publicly defined security broadly in the sense of it being developed for "the Iraqi people," and in 2003, DynCorp received \$50 million for the first year of a contract to create a new Iraqi police. But the Coalition's understanding of security was really about force protection, the safety of Coalition officials, and exit strategy. Additionally, while security provision was localized by indigenous sectarian militia, it was fragmented by Coalition authorities that subcontracted it to organizations and groups ranging from private security companies (PSCs) such as DynCorp to sheiks or Sunni groups capable of securing their own areas against insurgents. The resultant ambiguities ensured that security became a politically flexible notion. Thus PSCs were used to provide security for the head of the CPA, escort supply convoys, defend key locations in Baghdad's Green Zone, and also to interrogate prisoners. Twenty-seven of the 37 interrogators involved in the abuse of prisoners at Abu Ghraib prison belonged to CACI International, a Virginiabased private contractor, and 22 of the linguists who assisted them were from the California-based Titan International. Such civilian employers were effectively unaccountable, for they were not subject to military law or the Geneva Conventions, and Bremer had issued an order protecting them from local prosecution. 
Nonetheless, while this suggests that security's meaning may shift to reflect political contingencies, or, indeed, renewed fighting, inadequate food supplies, or the looting of hospitals, all of which refocus priorities, its primary meaning refers to something more physical, territorial and exclusionary. Western democracies may favour universalizing and inclusionary definitions, but security in the post-conflict city at least means that suicide bombers do not mutilate Coalition troops, and the local population is not forcibly displaced, raped, robbed, kidnapped, tortured or killed. The application of broad notions such as community, "human security" and social justice (let alone emancipation, as in Booth, 1991, p. 318) are of limited value in cities such as Baghdad ("Where the Strong," 2002) because the principal political weapons available are intimidation and violence. Threats are usually physical, or to do with the elusive notion of "survival," especially when cities are divided into ethnic or sectarian areas, and security's referent object is an identity or group (Compare Ayoob, 1995; Krause, 1998, p. 25). At a meeting between the UN and the governor of Afghanistan's Kandahar province in December 2002, the UN's officials spoke of building a civil society and a state, but the governor talked only of securing power in a continuing conflict ("Where the Strong," 2002).

Connected to this is territoriality. Territoriality is nowadays neglected, yet it is an integral facet of security's physical dimension and exclusionary tendencies. It is about asserting control over specific localities in order to expand a dominant group's space or restrict that of an adversary, and it tends to result in ghettoization (Compare Caldeira, 2000; Hoffman, 2007; Seekings, 2001). Territoriality expressed sectarian ambitions and fears in Baghdad, just as it prompted the use of communal terror to remap Vukovar, Sarajevo, and Mostar after the Balkan wars. Its influence is equally evident in the actions of conventional security forces. It drove the U.S. seizure of Iraq's symbols of regime power (including police headquarters) in 2003, just as it underpins the Israel Defence Force (IDF)'s attempts to control Palestinian movement by the destruction of Palestinian houses, infrastructure, and cultural and administrative facilities.

Territoriality emphasizes that security's meaning, production and provision are linked. Understood in this sense, production may be as critical as understanding.

\section{Paradigmatic Cases of Baghdad and Basra}

Baghdad, Iraq's capital, and Basra, its strategically important second city, provide paradigmatic cases of these characteristics from several perspectives. First, security in both cities was ghettoized. Just as the Coalition authorities were walled off in Baghdad's Green Zone, so Baghdad's districts were purged, divided into isolated neighbourhoods by concrete walls, barriers and checkpoints, and guarded by factional militia and gunmen. Similar trends are identifiable in Basra. Second, in both cities security was a symbol and a signal that had sense at many levels and referred to different things, but it was always understood in a brutally pragmatic fashion.

It could not be otherwise. After four years of insurgency and civil conflict, a national government existed in name only, three million Iraqis were internally displaced, some 3,000 were murdered each month, and many more were subject to 
kidnapping, rape, extortion, and robbery. The Iraqi Police Service (which was responsible for day-to-day policing) was little more than a sectarian militia, many of whose members were responsible for torture and extrajudicial killings (McCaffrey, 2007). This, despite receiving significant aid and support in kind from members of the U.S.-led coalition. The US alone spent \$194 million on rebuilding the police and military during its year of occupation (Barker, 2007), and by July 2006, the UK had disbursed £533 million to projects that included police training and mentoring (Hansard, 2006). Meanwhile Japan had given about \$1.5 billion in grant aid for comparable programs (“Iraqi Police," 2005).

Iraq shows how the Coalition's neo-liberal ideals of co-operation and democratization collided with Iraqi realities: greater Baghdad's estimated seven million inhabitants (and Basra's one million) understood security to mean the physical safety of themselves and their property. Pragmatic modes of manipulation, negotiation and accommodation amongst and between factional leaders, international agents and the populace soon developed into consistent patterns of domination and exclusion. This led to a ghettoization of security whereby specific groups are secure only in specific areas. Indeed, citywide security is rare because security (which is localized, superficial, and often temporary) is essentially the sum of myriad local arrangements. As Baghdad and Basra show, it is usually decided by mutually suspicious interactions between indigenous strong men, external agents, and influential sections of the populace (Stewart, 2007). It is a web composed of myriad groups, some of which understand the cultural rules guiding Iraqi (or American) behaviour and outcomes, and some of which do not.

The key fact about security is that its provision is a practical business. Coalition troops treated policing with a mix of ideology and pragmatism, especially once insurgency developed. The creation of a new police may have been part of the Coalition's strategy to bring democratic security to the Iraqi people (and thereby allow troops to depart), but the impassive and taciturn troops concerned combined casual acceptance of U.S. military power with an inexperience and lack of interest in the region that dehumanized Iraqis in their eyes (Etherington, 2005, pp. 196, 208, 219). At the same time, Coalition authorities consistently misunderstood the populace's concerns. Under Saddam security had been enforced by special units, heavy armour and checkpoints, arbitrary mass arrests, blackmail, torture and execution by brutal and unpopular security forces. In contrast, the CPA implemented programs on human rights, free markets, feminism and constitutional reform (Stewart, 2007, p. 82). But Iraqis talked only of their own physical security. And insecurity was made worse by the CPA's inability to control carjackings, kidnappings and the gangs smuggling diesel, and by the crumbling of traditional means of social control as young urban elites rejected sheiks who tried to reassert themselves (Stewart, 2007, p. 7).

But it is easy to overstate the significance of this, for (as Etherington notes) one thing U.S. troops shared with Iraqis was a practical understanding of security and policing. Inevitably, many Iraqis failed to see advantages in democracy, especially when it failed to provide protection, for their assessments were governed by "economic, social and local considerations, rather than national ones" (Etherington, 2005, p. 85). Almost all Iraqis thought that the biggest economic problem-and a major source of insecurity in that addressing it required them to venture out into unsafe streets-was unemployment; at least half of working age men were out of 
work. Iraqis were, however, unfazed by the Abu Ghraib scandal because that is how they thought the West always behaved. Stewart notes the Iraqis' standard response to insecurity: "Employ five times as many new policemen. Get heavier weapons. Impose curfews. Set up checkpoints . . . Establish secret services . . Be more brutal” (Stewart, 2007, p. 87).

\section{Security’s Multiple Meanings}

Insecurity was partly caused by many Iraqis being heavily armed, and partly by the stores of weapons and ammunition (including rocket-propelled grenades [RPGs], mortars and Katyusha rockets) left behind by the Ba'athist government. But it was worsened by the Coalition's inconsistent policies, which failed to control the deteriorating situation. One reason for the inconsistencies was that security had different meanings for the various actors involved. Coalition forces defined it in terms of their own physical safety, military objectives and operational success; security was about force protection and minimal own casualties, and Iraqi regulars, irregulars, and the urban terrain threatened it. To paraphrase Ayoob, security was defined in relation to the vulnerabilities that threatened danger and disorder (Ayoob, 1997, p. 130). But Iraqis had a different understanding based on their functional needs; Baghdad's inhabitants understood security to mean the physical safety and protection of themselves and their possessions.

Shaping and managing this environment so as to achieve the Coalition's strategic objectives called for robust but consistent and non-inflammatory forms of policing. In theory, the Coalition recognized its need to persuade Iraqis to do what it wanted but in practice its approach to policing failed to achieve this. Despite the rhetoric of freedom and liberty, the Bush administration's political vision and set of security practices were given public meaning and enabled by a specific and assertive rationality expressed in terms invoking punishment and pacification, or by appeals to democracy or the "Iraqi people," which failed to achieve its objectives.

Incoherence on the part of Coalition authorities increased the exclusionary nature of security provision. The CPA treated democracy and capitalism as integrated concepts, and the CPA's philosophy was that the Iraqi Police Service (IPS) would be democratically accountable, run according to modern principles of managerial efficiency and contemporary methods and technologies, and would ensure democratic forms of public order. However, policing was actually seen as secondary to economic development and a free market. Also, Washington assumed that conventional security could be provided independently of the relationship in which it was to be exercised. Thus police were recruited regionally on the basis that this would match the ethnic and religious balance of a region, rather than (as was the case) allegiance to local political leaders. And there were deep differences of opinion between military advisers from U.S. forces and civilian advisers from the State Department and Department of Justice (DoJ), too. Assumptions about the transferability of training programs were similarly controversial. Military advisers wanted to create a force capable of counter-insurgency, whereas civilian trainers wanted a lightly armed civilian police service that used Western investigative standards and community-policing techniques to remove terrorists and criminals. 
At the empirical level Washington's misunderstanding of the nature and potential role of policing and security governance as a strategic tool for managing its relations with Iraqis contributed to its use of provocative policies that increased the insecurity it sought to manage. Admittedly, Washington repeatedly emphasized its need to develop formal and informal partnerships with Iraqis so as to manage the prevailing insecurity (only then could the handover of sovereignty to Iraqi authorities in June 2004 be permitted), but it consistently misunderstood the relationships underpinning meaningful security. So did its troops, especially in the early days. That they misunderstood the situation is not in itself surprising. They were war fighters who were neither trained nor equipped to perform police functions or to manage public security. However, Baghdad was not the first time U.S. forces were confronted by a breakdown in public order, to which they responded heavy-handedly. Outbreaks had occurred in the aftermath of U.S. interventions in Panama, Haiti, Bosnia, and Kosovo, where the American response had been similarly heavy-handed.

Also, U.S. forces posed a risk to police, whose security was not their concern. U.S. spokesmen referred to troops acting in self-defence when police were killed, but many international commentators took a less charitable view of the response pattern that continued throughout the occupation. A representative case concerned the 10 Iraqi police who were killed in Falluja in July 2003 when the cars in which they were chasing robbers ran into American soldiers who opened fire in a gun battle that lasted 45 minutes. This came at a time when the US was emphasizing the value of Iraqi police co-operation in improving security across Iraq. But U.S. forces were widely perceived to have adopted a provocative approach that led to a cycle of Iraqi revenge attacks, retaliatory searches and mutual recrimination. In this way, U.S. actions were corrosive; troops were perceived to have killed or injured bystanders, accidentally or intentionally, while inadvertently or deliberately destroying property.

The existence of multiple understandings of security affected the British response in Basra too. The indifference of British forces to local politics, and their toleration of looting and sectarianism mean that security could never be more than partial as far as Basrawis were concerned. There was no common understanding of what security meant, and there were matter-of-fact limits as to how it was interpreted. Human Rights Watch recorded an extreme example in 2003: A Christian woman begged British soldiers for protection after religious militia threatened to kill her: "Tell her it’s not our jurisdiction," they said ("Life in Basra," 2003, p. 56). Understanding was in this way tightly linked to production and provision, usually to the disadvantage of the insecure.

\section{Providing Security}

There is nothing new about insecurity and incoherent policies. What is new is today's debate about who should provide city-wide security in the aftermath of international interventions, and the models on which it should be based. Troops are often used, but the objective of most militaries is not security as such. Rather, it is force protection and population identification and control. Also, urban operations are notoriously challenging, so troops normally avoid cities whenever possible, and when they cannot they focus on a city's terrain and density, and are suspicious of non-combatants, who may be hiding fighters. This may be a reason for the common 
Western assumption that police are best placed to provide long-term security, for in the West, the police role is oriented to answering two questions: "How safe am I in the here and now?" and "How well ordered is my immediate environment" (Innes, 2004). Admittedly, indigenous police tend to be static and inert, and are most aware of threats to their own safety, ethnic tensions and local power relations, but cities are police's workplace and livelihood. Even so, retaining or controlling territory or key points is less important for police than for militaries, though police stations are useful as fortresses in which to hide or to keep prisoners.

Admittedly, many associations and factional groups offer policing in post-conflict cities. In Maysan, for example, heavily armed militia known as Emergency Brigades had, along with other militia acting as Islamist vigilantes, established their own security organizations as the war ended, and were soon the only effective security presence in the province (Stewart, 2007, p. 423). Nonetheless, the role of state police is most significant because it is qualitatively different in its symbolic power, residual position and regulatory potential (Crawford, 2006, p. 137). Police resources (and their parent ministries) are desirable prizes for local strong men, but also police are thought to facilitate control and monitoring, signal credibility for international and national regimes, and offer benefits and sanctions for the population at large that may ensure a city's loyalty or acquiescence. Against that, policing is shaped by the social realities of its host society: corrupt, brutal or criminalized cities produce corrupt, brutal and criminalized police. Legacy issues matter, too, for they often mean that certain police cannot operate in certain areas, or that certain ethnic groups have never been recruited.

Despite this, liberal democracies think public police should, whenever possible, be responsible for functional security, and that policing models that respect the rights of all "citizens" and are responsive to their needs should be promoted. Iraq tests such assumptions. It tests the extent to which inclusive forms of security can be provided, and also, whether democratic policing based on a close relationship between respectfulness, responsiveness and effectiveness has meaning in violent cities. For in Iraq, as in most of the world, the police's primary purpose is not crime fighting, reassurance or protection for the populace at large. It is regime representation and the regulation of social order. Additionally, anecdotal evidence suggests that many Iraqis believe that police must be allowed to violate rights if they are to ensure security. This belief is reinforced by the widespread conviction amongst police that there are certain criminal or dangerous classes that represent a threat to the broader social order, and which therefore deserve fewer rights. Yet most international police advisers failed to question the transferability of their usual practices. Ignoring Iraqi realities, British police advisers argued that crowds could be controlled effectively but humanely by a small well trained lightly armed and citizen-friendly police service. They refused to allow the police to set up secret units or carry heavy weapons, and discussed instead the prospects of psychometric testing and genderawareness workshops for all (Stewart, 2007, pp. 83, 324, 335).

Stewart tells how by the time the Coalition authorities left the provincial capital of Maysan (to the northwest of Basra), the police had quadrupled in size, acquired heavier weapons, and, by establishing checkpoints every 500 yards up the highway, had brought some form of security. Some large tribal gangs had lost power, and there were fewer carjackings, kidnappings, smuggling and protection rackets. Only two 
forces - the Iranian-linked Badr militia and the Sadrists-remained outside the law. But "they were now the elected government" (Stewart, 2007, p. 423).

\section{Police as Producers}

The first question Paul Bremer asked when he arrived in Baghdad as head of the CPA a month after the 2003 war ended was: Where are the police? (Bremer, 2006). Like most Westerners, he expected the police to act as a cornerstone for democracy, and provide inclusive security, but this was never likely.

There were no police in Baghdad because officers had cast off or hidden their uniforms during the war, and the bureaucracy, buildings, procedures and political relationships on which the police institution was based were destroyed. Nevertheless, many officers responded to U.S. appeals that they return to work, and by mid-April some manned joint patrols with U.S. soldiers. In May a former interior ministry official and Ba'athist loyalist was appointed as Baghdad's police chief, though he was forced to resign a week later for refusing to implement procedures required by U.S. authorities (Rai, 2003). The formal remit of the new IPS was crime control, order maintenance, and assisting coalition forces (which retained responsibility for investigations involving terrorism and military crimes).

Bremer thought that it would be unacceptable to use police agencies associated with Saddam's regime, and one of the CPA's first acts was to dissolve the Ba'ath Party and purge Ba'athists from government positions. This left the police leaderless, with all that this implied for security provision. Also, Bremer underestimated the degree to which effective police depend on institutional structures. The Ba'ath party permeated every level of Iraq's administration, and public and private life, so the policy of killing or detaining even local Ba'ath leaders deepened the public security vacuum. So too did the policy of dismissing the many civil servants needed to support the police. Insecurity appeared to deepen and widen, religious vigilantes soon created alternative local security systems, and looting and street crime were subsumed into a more pervasive security crisis. Vetting ensured that Ba'ath party members were purged, and international attention focused on "professionalizing" the new police, but little really changed. Former senior and mid-level officers were removed, but most officers stayed in their stations, beating suspects and extorting bribes just as before the war, and, by 2007, sectarian militia groups infiltrated every level of policing. The Interior Ministry reputedly supplied militiamen with police uniforms and vehicles.

Sectarian groups fought for control of the police because it enabled them to augment their power, impose a particular morality, entrench factional or sectarian practices, and secure funds and weapons (Herring \& Rangwala, 2006, p. 268). And the police, in Iraq as elsewhere in the world, were content to be used. Regardless of rhetoric, regime, and resources, senior officers rarely build power bases comparable to those of the military. Some seek to preserve a minimal degree of operational and professional autonomy, but most are typically adjuncts to groups that control resources more directly. Most have personal patrons with whom reciprocal exchanges of favour are made. An additional factor in Iraq was that, while some officers may have claimed to represent the state, all shared the personal, tribal, or sectarian loyalties of their peers. Democratic accountability meant little because 
Iraqis valued appointments for the opportunities for patronage they offered; the primary task of individual clan members was to ensure the ascendancy of his group (tribe, family, or friends), and the dismissal of one officer meant dismissing a swathe of others too. The problems presented by incompetent or corrupt police were thus social, political, and institutional, with the police being not only a problem in its own right, but also one that exacerbated others (Etherington, 2005, p. 113).

The civilian police could not have managed city-wide security even if they had wanted to. By 2004 they were a faction in need of allies. They were not only ineffective and unreliable, but also were a symbol of pro-government forces and as such were targeted by sectarian militia and insurgents. In Baghdad as in cities such as Maysan in the south-east of the country, "no one was frightened of the police and the police were frightened of almost everyone" (Stewart, 2007, p. 83). When Etherington became head of a small CPA team in al-Kut (a provincial capital to the southeast of Baghdad) in October 2003, he found:

Police clustered in small groups on the steps of their stations and nearby fences like crows. There appeared to be thousands of them, in almost comical disarray. The police had no infrastructure, rules, leadership or staff worth the name; most had no weapons and few officers appeared to do any work though it was clear that many were directly implicated in widespread and systematic corruption if not criminal activity (Etherington, 2005, p. 27).

Most police could not run their own stations, let alone carry out security tasks (Etherington, 2005, pp. 137, 155). Poor leadership resulted in low morale that made the lower ranks lethargic and easily intimidated. When, for example, fuel shortages meant that they were sent to keep order in al-Kut's petrol stations, officers confined themselves to taking bribes from the queuing motorists in return for offering preferential treatment. They were then beaten up by motorists and fled (Etherington, 2005, p. 136). On the other hand, they were unarmed in the face of militia's Iranian Kalashnikovs and RPGs.

Police stations were frequently attacked, and factional fighting quickly increased as local power brokers forged or broke political and economic alliances. When this happened, some police shed their uniforms and joined the rebels while others put themselves under the protection of pro-rebel clergy; in late 2004, almost all of Mosul's police fled when insurgents attacked their stations, while Shia police in Najaf joined rebels from the Mahdi Army and handed over their weapons. As General Martin Dempsey (who led the Multi-National Security Transition Command) admitted to a Congressional hearing in 2007, more than 32,000 of the 180,000 newly trained and equipped police generated under Coalition schemes were no longer in the police. Approximately 8,000 had been killed in action, 6,000-8,000 were seriously wounded, 5,000 had deserted, and 7,000-8,000 were unaccounted for (“US General Warns," 2007). Numbers were impossible to determine since local chiefs inflated numbers to get funding, and individuals drifted in and out of service.

But recruitment was never a problem. Forty percent unemployment meant men applied regardless of the dangers of the job. Suicide bombings and roadside explosive devices aimed at recruiting stations, police convoys or military convoys escorting police account for many of the casualties, especially once the insurgency 
emerged in the summer of 2003. Most officers were unarmed and patrolling was suicidal, but men joined because the starting salary of an IPS officer in 2003 was 90,000ID (\$60) per month, with an additional 130,000ID (\$87) per month in hazardous duty pay (Chandrasekaran, 2007, p. 328; Herring \& Rangwala, 2006, p. 197). Police had no incentive to provide security for anyone except themselves.

\section{Expressions of Security}

It is difficult to map accurately the provision of security because so much is unknown. Despite their sophisticated technologies, American forces knew little about Iraqi police, let alone about trends in the localities in which their adversaries were based. The CPA's vision of security was, in any case, developed in isolation from Iraq's existing patterns of social and political domination and subjugation. It was rarely seen to address the concerns of most of the population, and when it did, the result was often incoherence and insecurity.

Within weeks of the occupation, swathes of Baghdad (which was strategically the critical city) were out of international control. Much of the burden of policing fell to U.S. troops, but they were neither trained nor equipped for it. Infantry complained they had not been trained in arrest procedures, tank crews were not equipped for foot patrols, M-1 tanks and Bradley fighting vehicles were too large to move through Baghdad's streets, and the imperatives of force protection meant troops could not engage with Iraqis even if they wanted to. Some 4,000 U.S. military police were eventually deployed in June, but there was little they could achieve; a force smaller than many U.S. metropolitan police departments was responsible for a looted city of several million inhabitants (Perito, 2003). Also, while security often improved when troop numbers increased, it declined when they left.

By mid-2004, when the CPA was dissolved, Iraq was divided into fiefdoms and factions, of which the U.S.-led coalition was only one, albeit the best resourced in material terms. The situation never improved. According to a review of security operations in Baghdad in February 2007, U.S. and Iraqi forces controlled 146 of Baghdad's 457 districts; that is, fewer than one-third of its neighbourhoods ("Most of Baghdad,” 2007). The review vividly illustrates the results of four years of Coalition operations: Iraqi police and army units failed to provide the forces necessary to carry out basic security tasks including manning checkpoints and conducting patrols; almost daily bombings caused misery in flashpoint districts. Sectarian violence remained serious in west Baghdad, and Shiite death squads continued to operate. In February 2007, for instance, most of the 100 bodies found dumped on rubbish dumps and street corners were Sunni who had been tortured before being shot. The deployment of more than 20,000 U.S. reinforcements temporarily halted the murders, but by May 2007 dozens of bodies were found in Baghdad every day. May also saw the third highest death toll of American soldiers (127) since the invasion. As ever, police melted away before incidents occurred.

The selective and practical nature of security_and the difficulty of making it more inclusive-is evident from this overview. It is also evident in crime levels. There had been low-level non-organized crime in the 1990s as sanctions and economic stagnation reduced living standards and encouraged the middle classes to emigrate, but this could not be compared to the situation from 2003 onwards. The 
disappearance of regime authority, the emptying of prisons, and the failure to control looting encouraged criminal violence. Home invasions, muggings and murders increased dramatically, together with carjacking, kidnappings, rapes, revenge killings, drugs trafficking and prostitution. From being almost non-existent in prewar Iraq, street crime became the primary concern of most Iraqis. Murder and kidnapping were especially problematic, not least because victims included more children, females, and the elderly than is usual in non-war environments. Additionally, kidnapping was about economics as well as retribution or sectarian hatred. As a Shia man said: "They kidnap 10 Sunnis, they get ransoms on five, and kill them all, in each big kidnap operation they make at least $\$ 50,000$, it's the best business in Baghdad” (Abdul-Ahad, 2007a). Many crimes went unreported because there was no one to report them to. Militia and groups subcontracting protection required payment. It was also difficult to distinguish between criminal violence, gang violence, political violence, and violence as a response to coalition violence. Crime was subsumed into an all embracing security crisis.

Differences of understanding resulted in lost opportunities to develop more inclusive forms of security. Arguably, there was a short window of opportunity in the first days of the occupation when the CPA, as the temporary but lawful government could, perhaps, have facilitated or imposed (symbolically or genuinely) a framework conducive to, or reflecting a more democratic form of security. But the moment was lost, and each passing week created more spoilers. Groups vying for political resources, turf control or profits quickly exploited potential security gaps. And the U.S. forces allowed them to gain the initiative. This was most evident in the Coalition's approach to looting. Its troops concentrated on defending selected public buildings, and they looked the other way as Iraqis engaged in wholesale looting in Coalition-controlled areas. Many Iraqis profited, but many more saw the looting as a symbol of the insecurity the Coalition tolerated or was thought to encourage.

Crucially, the omission or failure by Coalition forces to control looting or ensure public safety reinforced the conviction of Iraqis that their security was not a Coalition priority. Coalition authorities in both Baghdad and Basra sometimes allowed looting because it was thought to send a powerful message that the Coalition was in control. But this ignored the fact that disorder and insecurity primarily affected ordinary Iraqis who were already angry about water and electricity shortages, angry about civilian deaths from Coalition bombing, and resentful of foreign invasion. Many workers lost their source of livelihood because factories and shops were looted.

The situation was admittedly different when seen from the perspective of Coalition forces who, as the de facto occupying power, were obliged by international humanitarian law and convention to restore public order and safety. When questioned as to why forces stood by, senior officers usually argued that they lacked sufficient troops to protect cities and therefore focused on protecting vital infrastructure such as oil facilities and food warehouses. Other (low-ranking) troops thought looting was tolerated or encouraged as a cathartic reaction to the fall of Saddam's government. What was clear was that the combat troops in Iraq's cities at the end of the war were not trained to ensure civilian security; they were untrained for policing duties and by their actions often increased a sense of exclusion and insecurity, thereby exacerbating the security gap that emerged (Dziedzic, 1998).

Studies in Social Justice, Volume 3, Issue 1, 2009 


\section{Exclusionary Security in Baghdad and Basra}

Ironically, the desire for security was both a cause and result of the two dominating features of security in Iraq. It was ghettoized and sectarian.

\section{Ghetto Security in Baghdad}

Journalists such as The New Yorker's Jon Lee Anderson provide the best overview of how exclusionary security emerged in the days immediately after April 9, 2003, and what it meant in a city such as Baghdad. No soldiers or police were visible, no one observed traffic regulations, everyone was in a great hurry, buildings burned, and bombs and gunshot could be heard as gangs staked out their turf (Anderson, 2007, pp. 294, 315). Less than 24 hours later, most of the eastern side of central Baghdad had been looted. Defence secretary Rumsfeld dismissed looting with the comment that "freedom is untidy" (Loughlin, 2003), while General Tommy Franks, commander of U.S. forces, said that "people just go wild" when autocratic regimes fall, and that the true measure was how quickly the lawlessness was controlled (Alden \& McGregor, 2003).

There were pockets of heavy fighting and it "was not entirely clear which parts of Baghdad were in American hands and which were not" (Anderson, 2007, p. 311), but ghettoization began early, with armed vigilantes stopping cars, and residential streets barricaded and guarded. Localized order re-emerged, as when neighbourhoods, acting on the instructions of the Shia religious leader Ayatollah Ali Sistani, set up armed roadblocks to stop looters and retrieve stolen property. Anderson records how he went through a checkpoint manned by marines on the outskirts of Saddam City, a slum of 2.5 million, before driving into areas defended by roadblocks of zigzagged oil drums, furniture and cement blocks, which were guarded by "rough-looking youths ... holding iron bars” (Anderson, 2007, p. 317. Compare Clover 2004).

By April 14 Baghdad was divided into 55 to 60 zones, of which some 40 were under Coalition control. The U.S. officers in charge of civil administration met Iraqi police chiefs to discuss the "restoration" of law and order, by which time U.S. Humvees and armoured vehicle were on guard outside most of the main hospitals, and Iraqi police were (according to U.S. calculations) due to start patrolling. But such arrangements proved to be a veneer overlaying an increasingly localized and fragmented order, for when Anderson returned in the third week of July it was no longer safe to walk around. Increasingly, security provision reflected Baghdad's web of tensions, insecurities and violence. The US resisted calls to re-employ most police because it suspected their loyalties, while police wishing to return to work distanced themselves from the occupiers: "We came to protect the people, not to work with America” (Alden \& McGregor, 2003).

The CPA's dissolution in June 2004 made little difference. In the first month after the handover of sovereignty, the new government was under pressure to ensure security. But its claim to do so was rapidly undermined by innumerable incidents of violence, assassinations, kidnappings and explosions, many of which targeted the police. On July 28, 2004, for example, a massive car bomb exploded near a line of would-be police recruits in a centre of anti-government opposition north of Baghdad, killing 68. The government increased police patrols and checkpoints and mounted 
crime crackdowns, but internal politics meant that it failed to activate the emergency powers it had assumed after the transfer. The war may have finished some 15 months previously, but jihadists and nationalists fought an escalating battle for local control. Streets in Baghdad (as elsewhere) were under the control of rival militia competing to control territory and revenue sources such as oil and weapons smuggling.

Three linked elements or expressions of Baghdad's forms of security deserve note, each of which promoted exclusion. First, crime played a significant role in everyday life, while control of the black market and access to protection money helped to finance turf wars (Negus, 2004). For example, petrol stations were a desirable prize because they made money, were symbols of territorial control, and acted as recruiting stations, as they were gathering points for unemployed youths.

Second, the boundaries between criminality and sectarianism became increasingly blurred. By 2006, most killings were done by a handful of armed bands, vying for turf control or kidnapping members of other sects for profit ("Holding the Ring," 2006, p. 51). Some groups were not members of the Mahdi Army or Sunni insurgency groups so much as street gangs. Iraqi officers said that in the suburb of Adhamiya, for instance, the most dangerous were teenagers or in their early 20s, often drug addicts in it for thrills and prestige. The gangs were safe in their own districts, and had powerful protectors outside. This was evident from the way in which local Sunnis avoided using Baghdad's largest hospital complex a few kilometres to the south even though their own district had few resources. The reason was that the health minister was a radical Sadrist, and the medical complex used hundreds of Mahdi Army militants as security guards. In other areas, children banded together in 50-strong gangs to throw stones at U.S. troops, or they collaborated with Sunni kidnappers and robbers. One 13-year old told the UN that his family were unemployed so "I decided to help a gang specialized in kidnapping. For each kidnap I get US \$100 and it is enough to help my family with food for the whole month" (“Iraq Youth”, 2007, p. 51).

Third, the role played by the growing and politically active group of young, bored and urban slum dwellers was significant—and $40 \%$ of Iraqis were under 15 . Of these groups, the 10,000-strong Mahdi Army was the most noteworthy, not least because it policed its sphere of influence.

Created by the Shi'ite cleric Moqtada al-Sadr, the Mahdi Army originated as a small group in Sadr City where it provided security and welfare services, dispensing aid and preventing looting; Mahdi fighters patrolled on foot and in commandeered police vehicles. Formalized in June 2003, in some areas it amounted to a shadow government. Inspired by Sadrist themes of political marginalization, unequal suffering and exploitation, members claimed that the militia was a group of pious youths supporting their religion and clergy, rather than a military structure. In fact, it repeatedly clashed with Coalition forces. Armed with assault rifles, rocket propelled grenades, mortars, Strela anti-air missiles, and other light weapons, and using IEDs (improvised explosive devices), it seized control of public buildings and police stations. Later, its activities illustrated the role of security as a means to a political end: in June 2004, al-Sadr declared an end to operations in Sadr City, and sought to turn the Mahdi Army into a political party capable of contesting the 2005 election. Al-Sadr was seemingly co-opted by the authorities, but in fact agreeing a truce 
spared him from intrusive American raids while allowing his militiamen to act as roughly as ever in the suburbs.

\section{Sectarian Security in Basra}

Similar dynamics accompanied the re-emergence of order in cities such as Basra, $420 \mathrm{~km}$ south east of Baghdad, where the UK was the responsible power, and the sectarian infiltration of the police was particularly noteworthy.

By early 2006, the British approach to managing Basra's policing was to combine the prospect of improved training for the police with the threat of arrest in an attempt to create a more professional non-sectarian police. Enhancing the police's status was seen as a key factor in transferring security responsibility to Iraqis, and thereby allowing British withdrawal. According to Lt. Gen. Sir Robert Fry, the most senior British officer in Iraq, the process of handing over more control to Iraqis would provide an incentive to depoliticize the police, and ensure security for all.

This was unrealistic, for by then Basra belonged to militia, death squads and organized crime, and the British were merely one faction amongst many. Indeed, the temporary nature of their stay made them one of the weakest. For militias had seized the initiative in April 2003, when, immediately after the invasion, Sadrist mosques organized lorries to bring in water and used vigilantes to patrol the streets against looters. They then used the Allawi government's 2004 efforts to increase police numbers to embed militiamen into police. The result was that by October 2006, some 20 security and police groups operated with impunity; they ranged from a dozen religious militia, and the governor's 200 armed guards to the directorate of education police and the justice police (Abdul-Ahad, 2007b). Indeed, the appearance of a public police was illusory because the police comprised militiamen, and, in any confrontation between political parties, officers splintered according to party lines and fought one another. By May 2007 no one could be appointed to the police without a letter of support from a militia or political party. There was a rule of law, but it was militia law (Abdul-Ahad, 2007b), the main characteristics of which were sectarian division and physical violence.

The extent of sectarian brutality is evident in the activities of the so-called Jameat, a group of officers drawn from police intelligence departments and representing all the major factions. It was named after the police station its members were alleged to use as a base. When 1,000 British forces demolished the station in December 2006, they discovered 127 prisoners in the basement. Some had had their kneecaps shot off while others had electrical or cigarette burns, or crushed hands or feet. But most Iraqi police thought that torture was justified as a way of obtaining confessions and deterring retribution (Negus \& Rasan, 2005).

By then, the police were the equivalent of a sectarian militia. The ability of the 24strong team of British police advisers who, supported by 70 civilian private security staff employed by Armor Holdings (under contract to the Foreign Office), sought to influence them was minimal. Nominally British trained, the police were out of the control of both British and Iraqi authorities. As a senior general in the interior ministry said, "Most of the police force is divided between Fadhila which controls the TSU [the tactical support unit, its best trained unit] and Moqtada which controls the regular police ...” (Abdul-Ahad, 2007b). This meant that "Fadhila control the oil 
terminals, so they control the oil protection force ... Moqtada controls the ports and customs, so they control the customs, police and its intelligence. Commandos are under the control of Badr Brigade". Inevitably, officers who were not part of a militia joined in order to protect themselves. As a commander told a British journalist, once a policeman "affiliated with a militia then as a commander you can't change him . . . because then you are confronting a political party" (Abdul-Ahad, 2007b). Police cars openly carried pictures showing their factional allegiance. Other officers were politically neutral but had no interest in policing. General Hassan alSade, Basra's secular-minded chief of police admitted on May 30 that he had lost control of most of his 13,750 officers, and trusted only a quarter of them. A further complication arose from the fluid relationship between militias and the units they infiltrated. Whenever there was a clash between militias, the police split and units fought other units, switching identities according to whoever paid the most.

By the time British forces withdrew from central Basra in late 2007, the main factions had reached an understanding about sharing out Basra's resources; that is, running the police, controlling the revenues from oil smuggling, and the distribution of political power in the city.

\section{Conclusion}

Iraq tests the extent to which inclusive forms of security can be provided in postconflict cities, and it emphasizes the extent to which security is "a means of modelling . . . society around a particular vision of order” (Neocleous, 2008, p. 4). The Coalition's vision of inclusive security was expressed in an assertive rhetoric appealing to freedom, democracy and the "Iraqi people," but the reality was chronic insecurity, barricaded neighbourhoods, and a web of sectarian power relations that reflected a different rationale and vision. But this is not unusual. Post-conflict cities differ in location, culture, population, regime, significance, and experience, and the range of contextual factors and outcomes makes direct comparison of questionable value. Yet most, if not all, share certain features such as the fragmented, localized, and temporary nature of security provision, and ineffective or incompetent police.

Based on developments in Iraq, two general trends are identifiable. First, security is the central point around which discourse and competition take place. At the same time, it is as much a means to power and aggrandizement as it is to stability, personal safety or democratization. In other words, personalities, politics, and contingencies determine when and how security is understood, produced, and expressed, and the resultant exclusionary strategies are often rational. That there was tension between the various meanings was not a fundamental problem per se-military and/or individual security often have separate dimensions-but it was politically and practically significant. This implies that the notion of security can accommodate multiple interpretations, but in practice it cannot be understood in isolation from the political context in which it is to be employed.

Second, in the absence of city-wide security, factional groups provide localized arrangements. But there is little evidence to suggest that institutional structures such as the police in which international hopes are vested can ever provide security for all. Indeed, police typically operate according to sectarian or political imperatives. In 
other words, the provision of security depends on myriad environmental factors, and is often little more than a reconfigured complex of old elements and relationships, only some of which are revised and reoriented by new pressures and new or modified contexts. Empirically, security depends on agreements on rules, behaviour and predictability, many of which are inaccessible to external actors, and it is managed by coercion, manipulation and exclusion, as much as by negotiation and reform.

The successful introduction in 2007 and 2008 of a new U.S. strategy based on a "surge" of force and more police training does not refute this assessment. It is true that the strategy was heavily influenced by the argument of U.S. General David Petraeus that it was not enough for Coalition forces to provide a sustained military presence in volatile neighbourhoods, destroy insurgent sanctuaries, and hold cleared areas. They must also increase the capacity of the Iraqi government to create inclusionary employment projects, support tribal militia such as the so-called Awakening Councils, develop the role of the "Sons of Iraq" (a Sunni tribal militia that had turned against the jihadists linked to al-Qaeda in Mesopotamia), and improve everyday life for ordinary Iraqis (“General Petraeus," 2007). It is true, too, that the US's agenda shifted to accommodate some of the security concerns associated with sub-state groups and individuals, and its tactics increasingly balanced intimidation with inducement, yet the long-term significance of the resultant improvements in the security situation-let alone our theoretical understanding of security-is unclear. In May 2009, for instance, Ginger Cruz, the U.S. deputy inspector-general for Iraqi reconstruction, warned that many of the Sons of Iraq were rejoining the insurgency, and Shi'ite strong men (such as the prime minister, Nuri alMaliki) were re-emerging, with all that this implies for the selective emphasis of security (Rifat, Jaber, \& Baxter, 2009).

Comparable trends emerged in southern Iraq after U.S. forces assumed control from British authorities in March 2009. It is true that bombings and assassinations are still common, insurgents continue to operate in the provinces of Diyala and Ninevah (jihadists remain influential in Ninevah's main city, Mosul), the Mahdi Army remains a potential threat, politics is tainted by corruption and fraud, and the police are ineffective, yet Basra is relatively peaceful. Indeed, in January 2008 a coalition of parties won landslide electoral victories at the expense of Shia militia known as the Badr Brigades, which have ties to Iran (British forces had tolerated the Badr Brigades' activities, but Iraqi and American forces had earlier attacked and defeated them).

The implications of this for understanding security are uncertain. It may mean that international actors should intervene forcefully, rather than accept the reality of factionalized security arrangements, or it may mean that international expectations are now more realistic than they were in 2003. Whatever the case, there are few grounds for assuming that recent developments will facilitate the emergence of a coherent and comprehensive security concept. Questions remain even at the empirical level. For example, it may be that the new strategy effectively offered Basra's provincial council an opportunity to mitigate the exclusionary practices associated with previous security provision. It theoretically provided a space in which the council could provide electricity, potable water, sewage, employment, and education to all, thereby making a major improvement to everyone's quality of life, and enhancing the prospects for meaningful security and stability. Alternatively, it 
may be that violence declined due to the emergence of ethnically homogenous neighbourhoods; that is, illiberal forms of ethnic cleansing facilitated and/or enhanced security. In other words, the strategies of concession and accommodation made by state, sub-state and community actors have resulted in a form of security based on acceptable levels of selection and exclusion.

More generally, Iraq suggests that while today's broad definitions of security have normative, and also analytical, value, they ignore the discrimination common to post-conflict cities while assuming that the police can or should manage exclusionary tendencies. And they ignore also that reassurance, crime prevention and community policing are not what most police do. In other words, police cannot solve the social problems that broad definitions of security prioritize or act as moderating agents, even if they wanted to. Security (both for those who provide it, and often for those who want it) is a literal, rather than theoretical, construct, and the only certainty is that it means whatever powerful actors make of it.

\section{References}

Abdelhadi, M. (2003, July 6). Iraq rumour mill grinds on. BBC. Retreived from http://news.bbc.co.uk/

Abdul-Ahad, G. (2007a, January 27). 'If they pay we kill them anyway’-the kidnapper's story. Guardian. Retrieved from http://www.guardian.co.uk/

Abdul-Ahad, G. (2007b, May 19). 'Welcome to Tehran'-how Iran took control of Basra. Guardian. Retrieved from http://www.guardian.co.uk/

Alden, E. \& McGregor, R. (2003, April 14). Chaos in cities was inevitable, says Rumsfeld. Financial Times, p. 3.

Anderson, J. (2007). The fall of Baghdad. London: Abacus.

Ayoob, M. (1995). The Third World security predicament: State making, regional conflict and the international system. Boulder, CO: Lynne Rienner.

Ayoob, M. (1997). Defining security: A subaltern realist perspective. In K. Krause \& M. Williams (Eds.), Critical security studies (pp. 121-146). Minneapolis: University of Minnesota.

Barker, A. (2007, August 27). Total cost of conflict in Iraq hits £6.6bn. Financial Times, p. 2.

Booth, K. (1991). Security and Emancipation. Review of International Studies, 17(4), 313-326.

Bremer, B. with McConnell, M. (2006). My year in Iraq: The struggle to build a future of hope. New York: Simon \& Schuster

Caldeira, T. Pires do Rio. (2000). City of walls: Crime, segregation and citizenship in Sao Paulo. Berkeley, CA: University of California Press.

Chandrasekaran, R. (2007). Imperial life in the emerald city: Inside Baghdad's green zone. London: Bloomsbury.

Clover, C. (2004, April 23). The fighters of Falluja. FT Magazine. Retrieved from http://www.ft.com/

Crawford, A. (2006). Policing and security as 'club goods': The new enclosures? In J. Wood \& B. Dupont (Eds.), Democracy, society and the governance of security (pp. 111-138). Cambridge: Cambridge University Press.

Dziedzic, M., (1998). Introduction. In R. Oakley, M. Dziedzic \& E. Goldberg (Eds.), Policing the new world disorder: Peace operations and public security (pp. 3-8). Washington DC: National Defense University.

Etherington, M. (2005). Revolt on the Tigris: The Al-Sadr uprising and the governing of Iraq. London: Hurst.

General Petraeus’s Opening Statement. (2007, January 23). New York Times. Retrieved from http://www.nytimes.com/2007/01/23/world/middleeast/24petraeustextcnd.html?_r=1

Hansard (2006). Written answers 10 July 2006: Overseas projects. Retrieved from http://www.publications.parliament.uk/pa/cm200506/cmhansrd/cm060710/text/60710w1516.htm\#0607 1017000172

Herring, E. \& Rangwala, G. (2006). Iraq in fragments: The occupation and its legacy. London: Hurst.

Hoffman, D. (2007). The city as barracks: Freetown, Monrovia, and the organization of violence in contemporary West African cities, Cultural Anthropology, 22(3), 400-428. 
Holding the ring in the capital. (2006, August 31). The Economist, 51.

Innes, M. (2004). Reinventing tradition?: Reassurance, neighbourhood security and policing. Criminal Justice, 4(2), 151-171.

Iraq: Youth involved in anti-US attacks and kidnappings. (2007, February 23). IRIN. Retrieved from http://www.irinnews.org/

Iraqi police to get $\$ 3.3$ million in aid. (2005, October 13). Japan Times. Retrieved from http://japantimes.co.jp/

Johns Hopkins Bloomberg School of Public Health. (2006, October 11). Updated Iraq survey affirms earlier mortality estimates. Retrieved from http://www.jhsph.edu/publichealthnews/press_releases/2006/burnham_iraq_2006.html

Krause, K. (1998). Theorizing security, state formation and the "Third World" in the post-cold war world. Review of International Studies, 24(1), 125-136.

Lee, J. (1969). African armies and civil order. London: Chatto \& Windus.

Life in Basra: Making do, with difficulty. (2003, June 5). The Economist, 53.

Loughlin, S. (2003, April 12). Rumsfeld on looting in Iraq: 'Stuff happens.' CNN. Retrieved from http://www.cnn.com/

McCaffrey, B. (2007). Strategic and operational assessment of security operations in both Iraq and Kuwait-9 to 16 March 2007. British Army Review, 142, pp. 5-9.

Most of Baghdad 'not controlled.' (2007, June 5). BBC. Retrieved from http://news.bbc.co.uk/

Negus, S. (2004, August 22). Iraq's prized petrol stations fuel turf wars among militias. Financial Times. Retrieved from http://www.ft.com/cms/s/0/22f372a2-317b-11db-b953-0000779e2340.html

Negus S. \& Rasan, D. (2005, January 25). Iraqi torture of prisoners seen as open secret. Financial Times, p. 8.

Neocleous, M. (2000). The fabrication of social order: A critical theory of police power. London: Pluto.

Neocelous, M. (2008). Critique of security. Edinburgh: Edinburgh University Press.

Perito, R. (2003). Establishing the rule of law in Iraq. Washington, DC: United States Institute of Peace (USIP). Retrieved from http://www.usip.org/pubs/specialreports/sr104.htm

Rai, M. (2003). Regime unchanged: Why the war on Iraq changed nothing. London: Pluto Press.

Rifat, A., Jaber H., \& Baxter, S. (2009, May 3). Iraq bloodshed rises as US allies defect. Sunday Times. Retrieved from http://www.timesonline.co.uk/

Seekings, J. (2001). Social ordering and control in the African townships of South Africa: An historical overview of extra-state initiatives from the 1940s to the 1990s. In W. Scharf \& D. Nina (Eds.), The other law: Non-state ordering in South Africa (pp. 71-97). Cape Town: Juta.

Stewart, R. (2007). Occupational hazards. London: Picador.

US general warns on leadership shortage for Iraqi security forces. (2007, June 20). Jane's Defence Weekly. Retrieved from http://www.janes.com/

Where the strong spurn a weak state. (2002, December 20). Financial Times. 